\title{
Reconstructing the Holocene environments in the Russian sector of the Neman Delta area, Kaliningrad Region
}

\author{
Maxim NAPREENKO ${ }^{1, *}$, Tatiana NAPREENKO-DOROKHOVA ${ }^{1,2}$ and Alexandr MATUL ${ }^{1}$ \\ 1 Russian Academy of Sciences, Shirshov Institute of Oceanology, Nahimovskiy prospect 36, Moscow, 117997, Russian \\ Federation \\ 2 Immanuel Kant Baltic Federal University, A. Nevskogo 14, Kaliningrad, 236016, Russian Federation
}

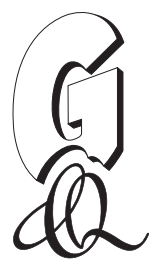

Napreenko, M., Napreenko-Dorokhova, T., Matul, A., 2021. Reconstructing the Holocene environments in the Russian sector of the Neman Delta area, Kaliningrad Region. Geological Quarterly, 65: 32, doi: 10.7306/gq.1600

Associate Editor: Wojciech Granoszewski

\begin{abstract}
A history of landscape development in the Russian part of the Neman Delta area during the Holocene, with an emphasis on the formation of forests and wetlands, is deduced based on pollen analysis, radiocarbon dating, a field topography survey, and macrofossil analysis of peat deposits in a coastal mire, the Koz'ye Bog. Several 1,000-2,000-year time lags in vegetational development were revealed here, though they have not been recorded for other landscapes in the Kaliningrad Region and the adjacent areas in the southeastern Baltic. The causes are still not completely clear, but they presumably related to some of the regional patterns of climate development and the submergence of the area during the second Littorina transgression (7,500-7,000 cal. yr BP). It is established that cryophilic open tundra-like vegetation existed here not only in Late Glacial time (Younger Dryas) but up to the mid-Boreal (9,700-9,500 cal. yr BP). A transition from the open landscapes of the Late Glacial to birch and then pine forests occurred here 9,700-8,700 cal. yr BP, whereas the expansion of thermophilic broadleaf species of the nemoral (temperate) association (Quercus, Ulmus, Tilia, Corylus) was recorded only in the period 6,400-3,500 cal. yr BP. Peak expansion of Alnus occurred here only in the late Subboreal (3,500-2,700 cal. yr $\mathrm{BP})$, while in adjacent areas it reached its maximum as early as the Atlantic. The general vegetation dynamics in this area during the Late Glacial and the Holocene could be referred to as a transition from the dominance of pine forests to a wide dispersal of alder carrs. This environmental shift was caused not only by climatic factors but probably also due to the transformation of the hilly coastal terrace into a low-lying plain landscape after flooding during the transgressions of the Baltic.
\end{abstract}

Key words: palaeoreconstruction, palynology, plant macrofossils, Holocene peat core, Neman Delta, Baltic Region.

\section{INTRODUCTION}

Investigation of Holocene palaeoenvironments is relevant to understanding recent environmental change, commonly associated with climate change and ecosystem transformations, since the main features of present-day landscapes were formed in the Holocene.

The development of the present-day landscapes in the Kaliningrad Region took place in several stages that were closely related to deglacial phases during the transition from the last Valdai (Weichselian) glacial to the Holocene. At the same time, some young landscapes in the region are still in a stage of active formation. Included among these is the deltaic lowland of the Neman River (Fig. 1B) which represents a specific coastal landscape area in the southeastern Baltic Region (Timofeev and Bogolyubova, 1998).

\footnotetext{
* Corresponding author, e-mail: maxnapr@gmail.com
}

Received: December 31, 2020; accepted: May 10, 2021; first published online: July 1,2021
During the last couple of decades, many publications have detailed comprehensive high-resolution studies of Holocene palaeogeography and palaeoclimate in the southeastern sector of the Baltic Region, mostly in Poland and Lithuania including their coastal areas (e.g., Ralska-Jasiewiczowa et al., 2004; Kabailiené, 2006; Damušytè, 2011; Apolinarska et al., 2012; Gałka et al., 2014). Based on a large number of dated samples and multi-proxy diagrams, the Holocene development of different coastal areas in this region was established in detail, including as regerds Baltic sea-level fluctuation and stratigraphy issues. There are few similar studies for the Kaliningrad Region. Meanwhile, coastal lagoons, lakes and peatlands in the alongshore zone of the Russian sector of the southeastern Baltic are of great interest for palaeogeographic investigation, which could add to the high-resolution Holocene palaeoreconstructions of the whole Baltic Region.

Our study is analyses patterns of landscape formation in the Neman Delta area (Fig. 1) after the last glacial retreat, taking into account their probable correlation with Baltic sea-level oscillations. We focus on the reconstruction of palaeovegetation and palaeoecosystem development inferred from palynological, macrofossil, radiocarbon, and topographical data. We discuss the comparison between our results and the well docu- 


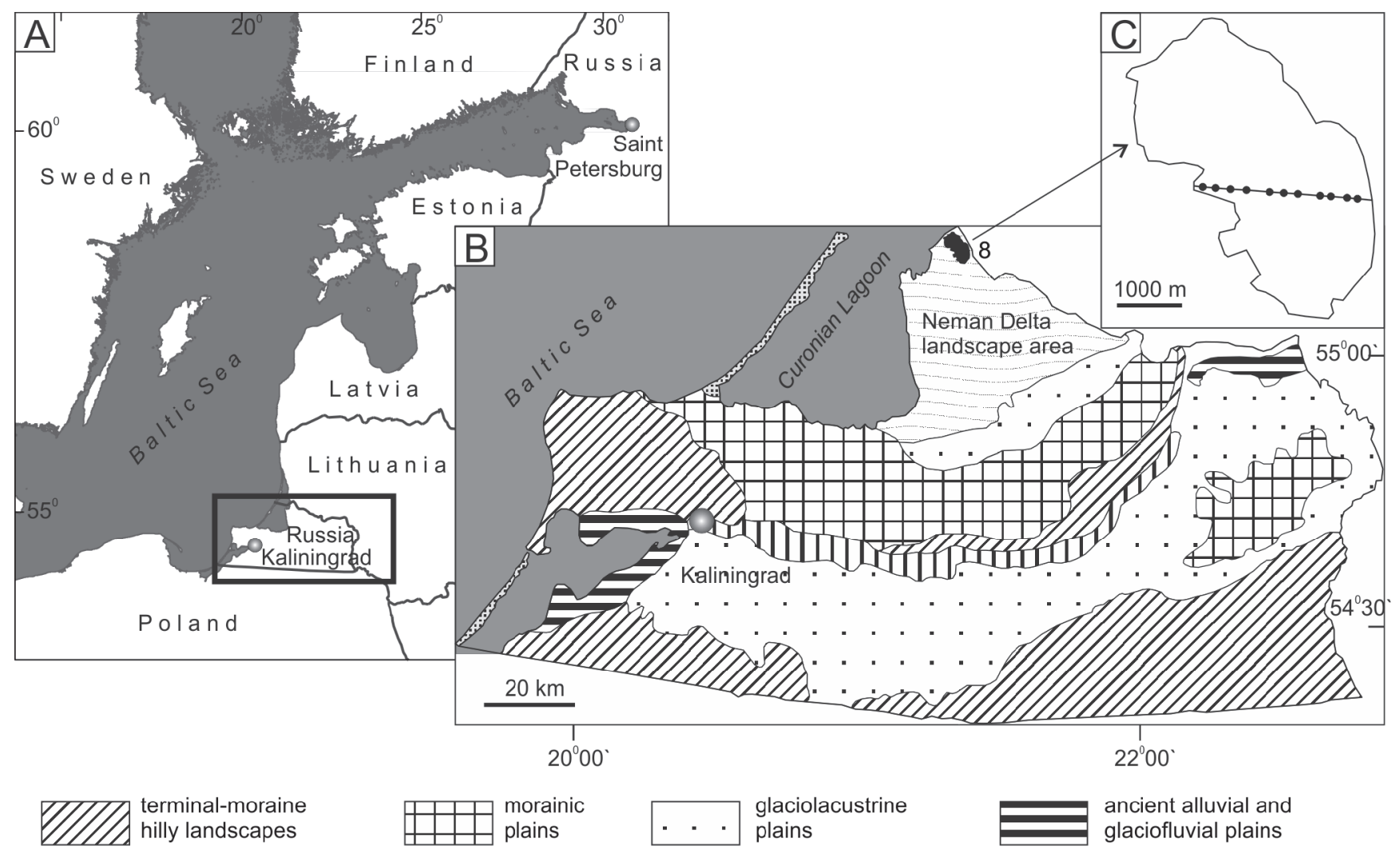

$\prod \prod \prod \begin{aligned} & \text { recent alluvial } \\ & \text { plains }\end{aligned}$

deltaic lowlands (Neman Delta landscape area)

aeolian landscapes

Koz'ye Bog

Fig. 1. Sketch map of the study area

A - geographic location of the Kaliningrad Region; B - types of landscape in the Kaliningrad Region (according to the map by N.N. Lazareva in: Orlionok, 2008); C - area of Koz'ye Bog with location of the study transect line and borehole sites (black circles)

mented records from sedimentary deposits of adjacent regions in the southeastern Baltic.

\section{MATERIAL AND METHODS}

A large coastal raised bog, Koz'ye (Kaliningrad Region, Russia, $55.25500^{\circ} \mathrm{N} ; 21.39000^{\circ} \mathrm{E}$ ), was chosen as a study site due to it being an undisturbed ecosystem which is located in the northern part of the Neman Delta close to the mouth of Neman River and also to the shore of the Curonian Lagoon (Fig. 1B). According to geological data (Timofeev and Bogolyubova, 1998), the 0-level of the bog's peat bed lies $\sim 2 \mathrm{~m}$ above the level of the Curonian Lagoon (Fig. 2). The study area is considered to be a key site for the reconstruction of landscape formation in this coastal zone. The palaeoinformation obtained from this site has been compared with that of the right-bank area of the Neman Delta (Bitinas et al., 2002; Damušyté, 2011). This provides an opportunity to develop a complete history of this trans-boundary area in the southeastern part of the Baltic Region.

The Koz'ye raised bog occupies an area of 1,400 ha within a mosaic landscape surrounded by various habitats such as flooded black-alder carrs, ancient dunes, floodplain meadows and fens which together comprise a reference ecosystem for the Neman Delta area.

\section{PEAT BED PROBING AND SAMPLING}

Field investigations were made along an axis (transect line) running across the whole mire area from east to west (Fig. 1C). The survey included the following operations according to standard techniques (Minkina, 1939; Vleeshouwer et al., 2010): a levelling procedure to determine the bog surface topography, manual peat bed probing to estimate the floor relief of the bog depression, selective coring of the peat bed and the collection of peat samples.

Levelling was carried out using an $\mathrm{H}-10$ level, every $50 \mathrm{~m}$. Peat depths were measured manually using a Russian peat corer fitted with a probe chamber (TBG-66 model) at $50 \mathrm{~m}$ intervals along the transect line until the point of resistance (Fig. 2), whereas the sites with an abrupt change in bog floor relief were probed every $20 \mathrm{~m}$.

The peat bed coring and retrieval of peat samples was carried out using a Russian peat corer with a semi-cylindrical sample chamber (TBG-1 model) which is fitted with a semi-cylindrical cutting blade to provide undisturbed sediment monoliths. Sampling was carried out at $10 \mathrm{~cm}$ intervals of the retrieved core, with the exception of segments with a high degree of heterogeneity, in which case samples were taken at $5 \mathrm{~cm}$ intervals. We obtained 11 cores $150-700 \mathrm{~cm}$ in length, picking out 346 samples from across the whole profile of the bog site studied (Fig. 2). 


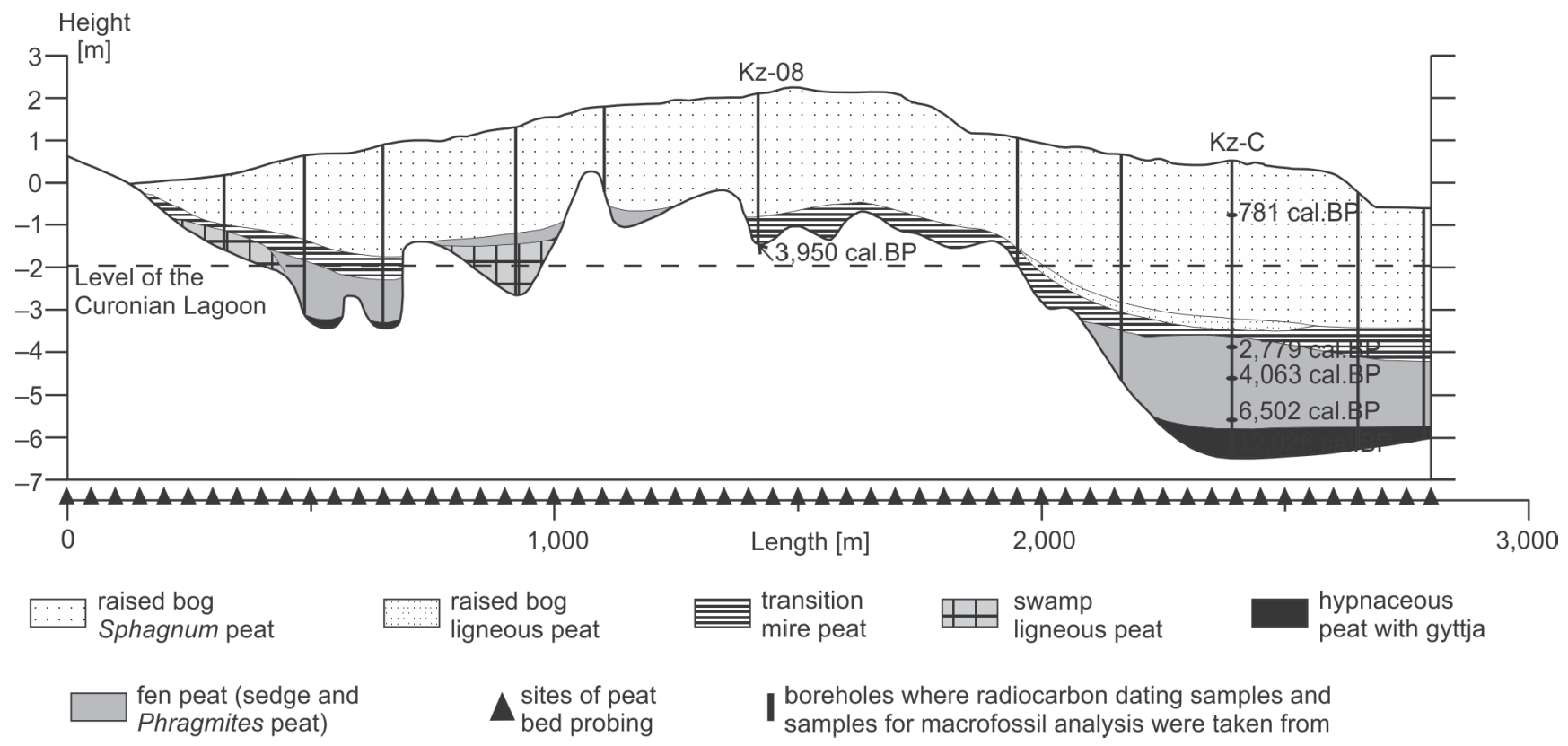

Fig. 2. Lithostratigraphic cross-section of Koz'ye Bog

The level of the Curonian Lagoon is given following correlation with the scheme in Timofeev and Bogolyubova (1998)

\section{RADIOCARBON DATING}

The numerical age of the deposits was determined by radiocarbon dating of several peat horizons in the deepest borehole $\mathrm{Kz}-\mathrm{C}\left(55.25234^{\circ} \mathrm{N} ; 21.40882^{\circ} \mathrm{E}\right)$ and the bottom peat in the central borehole $\mathrm{Kz}-08\left(55.25213^{\circ} \mathrm{N} ; 21.39477^{\circ} \mathrm{E}\right)$. We obtained seven radiocarbon dates for the bulk peat samples (incl. fen, swamp, transition mire and raised bog peat) which were processed using the conventional scintillation-counting technique (LSC) in the Radiocarbon Laboratory of the Institute of Geography, Russian Academy of Sciences (Moscow, Russia, laboratory index "IGAN"). For the lower part of the core Kz-C, we also received two AMS radiocarbon dates processed in the Poznań Radiocarbon Laboratory (Adam Mickiewicz University, Poland, laboratory index "Poz"). The results of the radiocarbon dating are given in Table 1.

The radiocarbon dates obtained were calibrated using the programme CALIB (version 8.2 ${ }^{14}$ ChronoCentre, Queens University Belfast) by means of the calibration curve IntCal20 (Stuiver et al., 2020). The calendar age is presented as a mean value within the confidence interval of the calibration curve $+1 \sigma$ (Table 1).

The age model of the core was constructed by linear interpolation between the calibrated radiocarbon dates.

Taking into account that some very closely located peat horizons were dated with different, AMS and conventional, radiocarbon techniques and gave very discrepant dates (samples $4 / 5$ and $7 / 8$ in Table 1), we have excluded the three lower ${ }^{14} \mathrm{C}$ conventional dates (5, 6 and 7 in Table 1) from the interpolation procedure due to their lower reliability.

Based on the data of interpolation, the age-depth model was plotted for Koz'ye Bog (Fig. 3) using OxCal software v4.3.2 (Bronk Ramsey, 2017).

\section{PLANT MACROFOSSIL ANALYSIS}

Each of the 346 peat and gyttja samples were subjected to macrofossil analysis, which included a study of the degree of peat decomposition and the botanical structure of the plant remains. The estimation of the degree of peat decomposition was accomplished using both microscopic and elutriation techniques (Piavtchenko, 1963). In order to determine a peat type and a peat-forming plant community (thanatocoenosis), a botanical analysis of plant macrofossils in the peat was performed for each sample by microscopicy. Remains such as rootlets, fragments of rhizomes, leaves, stems, bark, epidermis and pieces of wood were identified to species level using a range of identification keys (Korotkina, 1939; Matyushenko, 1939; Dombrovskaya et al., 1959; Katz et al., 1977). Local macrofossil zones have been visually defined according to the compositional and dominance patterns of the different plant remains. Based on the results of the macrofossil analysis of the longest $(7 \mathrm{~m})$ core $(\mathrm{Kz}-\mathrm{C})$ a diagram of vegetational successions (Fig. 4) was plotted using C2 software (Juggins, 2014). A lithostratigraphic cross-section of Koz'ye Bog (Fig. 2) was generated by correlation of the macrofossil data from each of the 11 peat cores, retrieved along the transect line, whilst taking into account the mire floor relief and bog surface topography.

\section{POLLEN ANALYSIS}

Pollen analysis was conducted on 97 peat and gyttja samples collected from horizons $(705-6 \mathrm{~cm})$ of the core $\mathrm{Kz}-\mathrm{C}$ retrieved from the deepest part of the bog. Samples were processed according to the Faegri-Iversen technique (1989) for preparation of pollen/spore specimens. Specimens were microscopically examined under 400-X magnification for species identification following standard identification keys (Kupriyanova and Alyoshina, 1972; Göttlich, 1990; Faegri and Iversen, 1993; Beug, 2004; Nelle, 2008). We counted no less than 400 arboreal pollen grains in each sample.

The pollen diagram (Fig. 5) was plotted using C2 software (Juggins, 2014). The percentage of taxa was calculated based upon the total terrestrial pollen sum, arboreal pollen (AP) plus non-arboreal pollen (NAP). Pollen from aquatic plants, spores 
Radiometric dating of the peat samples from Koz'ye Bog

\begin{tabular}{|c|c|c|c|c|c|c|c|}
\hline No. & Lab. no. & $\begin{array}{l}\text { Depth of sampling } \\
\mathrm{cm} / \text { core no. }\end{array}$ & Dated material & Dating method & $\begin{array}{c}\text { Radiocarbon age } \\
\left({ }^{14} \mathrm{C}\right) \\
\text { yr BP }\end{array}$ & $\begin{array}{l}\text { Calibrated age } \\
\text { for } 1 \sigma \text {, cal. } y \\
\text { beginning-end }\end{array}$ & $\begin{array}{l}\text { interval } \\
\text { yr BP } \\
\text { probability }\end{array}$ \\
\hline 1 & IGAN-4757 & $125-135 / K z-C$ & $\begin{array}{c}\text { raised bog peat, } \\
\text { weakly decomposed } \\
\text { (bulk sample) }\end{array}$ & $\begin{array}{l}{ }^{14} \mathrm{C} \text { conven- } \\
\text { tional }\end{array}$ & $890 \pm 90$ & $\begin{array}{l}\frac{728-834}{844-859} \\
863-908 \\
\end{array}$ & $\begin{array}{l}\mathbf{0 . 6 5 0} \\
0.082 \\
0.267 \\
\end{array}$ \\
\hline 2 & IGAN-4758 & $435-450 / K z-C$ & $\begin{array}{c}\text { fen peat, highly de- } \\
\text { composed } \\
\text { (bulk sample) }\end{array}$ & $\begin{array}{l}{ }^{14} \mathrm{C} \text { conven- } \\
\text { tional }\end{array}$ & $2,630 \pm 70$ & $\begin{array}{l}2,622-2,627 \\
\underline{2,708-2,850} \\
\end{array}$ & $\begin{array}{l}0.018 \\
0.982 \\
\end{array}$ \\
\hline 3 & IGAN-5243 & $505-515 / K z-C$ & $\begin{array}{l}\text { fen peat, moderately } \\
\text { decomposed } \\
\text { (bulk sample) }\end{array}$ & $\begin{array}{l}{ }^{14} \mathrm{C} \text { conven- } \\
\text { tional }\end{array}$ & $3,720 \pm 70$ & $\begin{array}{l}3,932-3,942 \\
3,973-4,153 \\
4,208-4,220 \\
\end{array}$ & $\begin{array}{l}0.032 \\
0.930 \\
0.038 \\
\end{array}$ \\
\hline 4 & Poz-123134 & $605-607 / \mathrm{Kz}-\mathrm{C}$ & $\begin{array}{c}\text { fen peat, } \\
\text { highly decomposed }\end{array}$ & ${ }^{14} \mathrm{C}$ AMS & $5,720 \pm 40$ & $\frac{\mathbf{6 , 4 4 4 - 6 , 5 6 0}}{6,594-6,596}$ & $\begin{array}{l}0.989 \\
0.011\end{array}$ \\
\hline 5 & IGAN-5244 & $610-620 / K z-C$ & $\begin{array}{c}\text { fen peat, } \\
\text { highly decomposed } \\
\text { (bulk sample) }\end{array}$ & $\begin{array}{l}{ }^{14} \mathrm{C} \text { conven- } \\
\text { tional }\end{array}$ & $6,600 \pm 80$ & $\frac{7,429-7,515}{7,535-7,566}$ & $\begin{array}{l}\mathbf{0 . 7 4 1} \\
0.259\end{array}$ \\
\hline 6 & IGAN-4762 & $655-670 / \mathrm{Kz}-\mathrm{C}$ & $\begin{array}{l}\text { fen peat, } \\
\text { highly decomposed } \\
\text { (bulk sample) }\end{array}$ & $\begin{array}{l}{ }^{14} \mathrm{C} \text { conven- } \\
\text { tional }\end{array}$ & $8,340 \pm 80$ & $\frac{9,273-9,469}{9,153-9,166}$ & $\begin{array}{l}0.953 \\
0.047\end{array}$ \\
\hline 7 & IGAN-4763 & $685-700 / K z-C$ & $\begin{array}{c}\text { fen peat, } \\
\text { highly decomposed } \\
\text { (bulk sample) }\end{array}$ & $\begin{array}{l}{ }^{14} \mathrm{C} \text { conven- } \\
\text { tional }\end{array}$ & $8,760 \pm 80$ & $\begin{array}{l}9,654-9,897 \\
9,559-9,571 \\
9,602-9,649\end{array}$ & $\begin{array}{l}\mathbf{0 . 8 3 3} \\
0.031 \\
0.135 \\
\end{array}$ \\
\hline 8 & Poz-123136 & $700-702 / \mathrm{Kz}-\mathrm{C}$ & $\begin{array}{l}\text { fen peat, } \\
\text { highly decomposed }\end{array}$ & ${ }^{14} \mathrm{C}$ AMS & $10,320 \pm 60$ & $\begin{array}{l}\mathbf{1 1 , 9 4 4 - 1 2 , 1 0 8} \\
12,113-12,176 \\
12,235-12,253 \\
12,307-12,324 \\
12,356-12,377 \\
12,391-12,438\end{array}$ & $\begin{array}{l}\mathbf{0 . 5 2 8} \\
0.181 \\
0.049 \\
0.046 \\
0.054 \\
0.142 \\
\end{array}$ \\
\hline 9 & IGAN-4764 & 340-350/Kz-08 & Transition mire peat & $\begin{array}{l}{ }^{14} \mathrm{C} \text { conven- } \\
\text { tional }\end{array}$ & $3,650 \pm 60$ & $\frac{3,891-4,007}{4,031-4,083}$ & $\begin{array}{l}0.703 \\
0.297\end{array}$ \\
\hline
\end{tabular}

and algal coenobia (Pediastrum boryanum) were not included in the total pollen sum, and their frequency values were calculated in relation to the sum AP + NAP. To calculate pollen concentration in $1 \mathrm{~cm}^{3}$ of sediment, Lycopodium clavatum tablets were added to the samples prior to the maceration (Stockmarr, 1971).

Local pollen assemblage zones (LPAZ) were visually distinguished by AP and NAP interrelation, taking into account their appearance and extinction in the diagram, as well as the considerable frequency change compared to other species. LPAZ are defined as intervals where the pollen of a species reaches peak content in a horizon and where some species appear / decline (Boitsova, 1977).

\section{CHRONOSTRATIGRAPHICAL CORRELATION}

As regards subdivision of the Holocene Epoch, we use definitions 'early', 'middle' and 'late' Holocene basing on the recently adopted scheme of the International Commission on Stratigraphy (Walker et al., 2018), which considers global climatic events. Nevertheless, we also match our data with the traditional chronozones of the Blytt-Sernander classification (in Khotinsky, 1977; Mangerud et al., 1982). The latter is still in use in Russian and European palaeogeography and, in our opinion, is better applicable for describing the variations of vegetation at local or even regional scale in the Baltic Region. The units of these subdivisions can be approximately correlated between each other and with the scheme of Neustadt (1957), which also uses the terms 'early', 'middle' and 'late' Holocene (Table 2).
All the local zones and stages in the diagrams (Figs. 4 and 5) are matched with the Blytt-Sernander chronozones according to the juxtaposed stratigraphic scheme of Kabailienè (2006) and the scheme of the developmental stages of the Baltic Sea (in Damušytè, 2011).

\section{RESULTS}

\section{FIELD STRATIGRAPHY AND MACROFOSSIL CORRELATION} OF THE CORES

Some preliminary data on the stratigraphy of Koz'ye Bog, based on the botanical composition of the peat, was published earlier (Napreenko-Dorokhova et al., 2017; Napreenko-Dorokhova and Napreenko, 2018). Here we summarise the data and add new detail reflecting our latest records.

The analysis of the 11 field cores from the peat deposits shows that there are two distinct basins of the Koz'ye Bog peat, each being separated into several minor kettles (Fig. 2). The underlying sand deposit rises in the centre, forming an inner bar which is, apparently, a remnant ridge from the ancient dunes.

The deepest point was recorded in the eastern large kettle at a depth $7 \mathrm{~m}$ from the surface $(4.5 \mathrm{~m}$ below the water level of the Curonian Lagoon). According to the radiocarbon dating, this major kettle contains the oldest peat deposits and may be the genetic centre of the entire mire.

The macrofossil analysis of the 346 peat samples enabled us to define 17 botanically inferred peat units (Napreenko and 


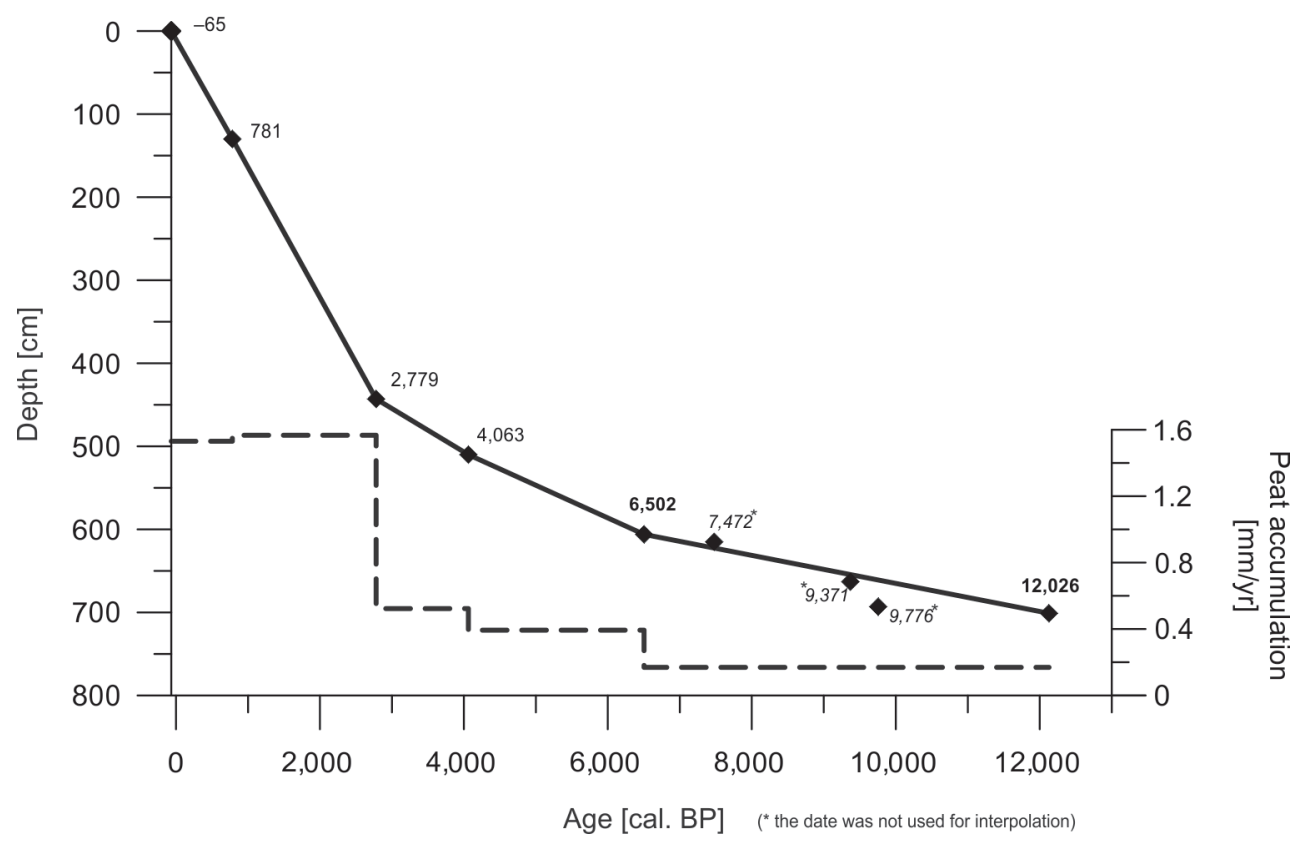

Fig. 3. Age-depth model and a peat accumulation curve (dashed line) for Koz'ye Bog

AMS-dates are marked in bold; see Table 1 for details of radiocarbon dates

Napreenko-Dorokhova, 2015), these 17 units being further classified into 6 specific types of peat. The latter are listed in the legends of Figures 2 and 4. The lithostratigraphic cross-section of Koz'ye Bog is based on the correlation of these peat types, which were arranged along the profiles of the 11 retrieved peat cores (Fig. 2). When combined with the radiocarbon dating the cross-section illustrates the main stages of mire development during the Holocene.

Most of the fen and transition mire peat deposits lie below the level of the Curonian Lagoon whilst the majority of the raised bog peat is above this level.

\section{AGE-DEPTH MODEL}

Figure 3 gives the age-depth model for the peat of the Koz'ye Bog in the core Kz-C accompanied by a plot of the peat increments. Four conventional dates for the upper peat samples and two $\mathrm{AMS}{ }^{14} \mathrm{C}$-dates for the lower horizons provide six age reference points for the whole peat bed. In spite of the fact that the three dates: 7,472; 9,371 and 9,776 cal. yr BP, lie in the vicinity of the curve, they are not included in the calculations, being less reliable.

The average accumulation rate of the peat was very low $(0.2-0.4 \mathrm{~mm} / \mathrm{yr})$ during of 9,000 year interval between $12,100-2,800$ cal. yr BP, within the Late Glacial to the beginning of the Late Holocene. An abrupt shift to more active peat accumulation started from the beginning of the Subatlantic chronozone $(2,800$ cal. yr BP), reaching the rate of $1.6 \mathrm{~mm} / \mathrm{yr}$.

\section{PLANT MACROFOSSIL DATA}

Figure 4 shows the macrofossil distribution through the $7 \mathrm{~m}$ long peat core $\mathrm{Kz}-\mathrm{C}$ from the deepest kettle in the eastern part of the mire. The eight macrofossil zones represent the pattern of mire development in the study area during the Late Glacial and Holocene time.
Macrofossil zone I (700-645 cm, 12,200-8,600 cal. yr BP). The predominant plant macrofossils are the residues of a hydrophilic moss Drepanocladus sp. that reached $>90 \%$. The remains of Phragmites australis, Menyanthes trifoliata and Alnus glutinosa are continuously present in the lower part of the zone (5-30\%), but disappear towards the middle. Carex lasiocarpa is present in negligible amounts but rapidly increases towards the top.

Macrofossil zone II (645-583 cm, 8,600-6,000 cal. yr BP). This zone is defined by a rapid decline in the percentage of Drepanocladus $(<5 \%)$. Phragmites australis and Carex lasiocarpa become the dominant taxa (30-50\%). Alnus glutinosa appears at the top of the previous zone and is recorded here at all levels but in very low amount $(<5 \%)$.

Macrofossil zone III (583-472 cm, 6,000-3,400 cal. yr BP). Carex lasiocarpa becomes the dominant species, reaching 80-90\%. The other fen species (Drepanocladus, Phragmites australis, Menyanthes trifoliata and Alnus glutinosa) decrease to $\sim 1-5 \%$. The plant residues represented by the smallest percentages $(1-2 \%)$ are those of the transition mire species Eriophorum vaginatum and Pinus sylvestris.

Macrofossil zone IV (472-382 cm, 3,400-2,350 cal. yr BP). Minerotrophic species (Phragmites australis, Menyanthes trifoliata and Alnus glutinosa) are abundant in the first half of the zone but they decrease towards the top. In the upper part, Eriophorum vaginatum and Pinus sylvestris are dominant (50-80\%), and Sphagnum species (1-5\%) appear.

Macrofossil zone V (382-134 cm, 2,350-800 cal. yr BP). The dominant species is Sphagnum fuscum which makes up $80-95 \%$ of the plant residue. Other species of Sphagnum are insignificant. The percentage of Eriophorum vaginatum varies from 2 to $15 \%$.

Macrofossil zone VI (134-81 cm, 800-400 cal. yr BP) is characterized by the dominance of hydrophilic taxa. Sphagnum balticum and $S$. cuspidatum are the predominant species $(60-70 \%)$, the residues of $S$. angustifolium/S. fallax group be- 


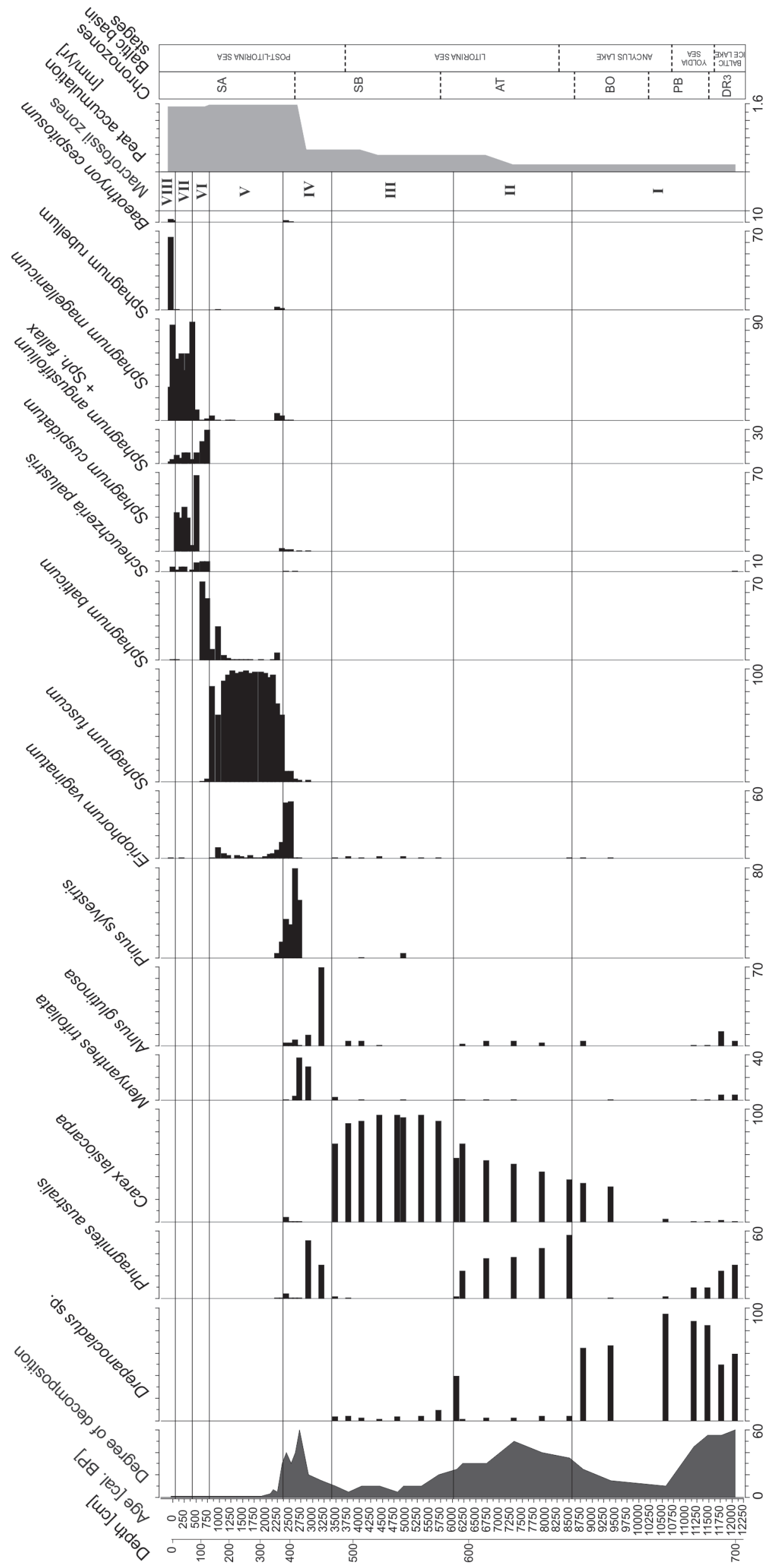

훙워

30 跑

今.

क्ष

ว 웡

$1 \quad \sigma>\frac{5}{0}$

ब 1

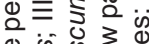

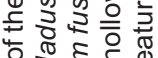

응

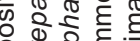

होi की

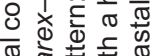

잉

西虫

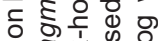

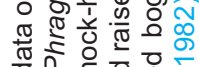

舟

당 $\frac{5}{\pi} \frac{1}{4}$

3 की

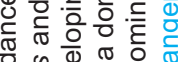

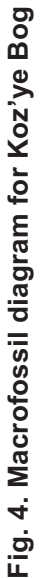

要

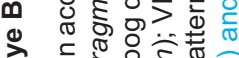

N

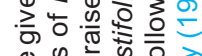

市

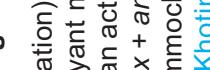

해응

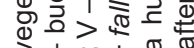

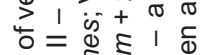

क क i

勿

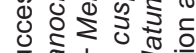

क्⿹

कू

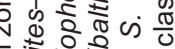

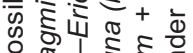

은 온

क्षे के के

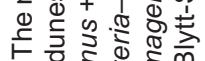

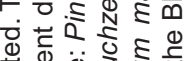

券

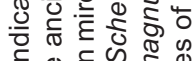

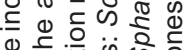

造

on

ه잉

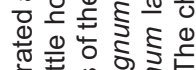

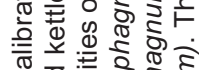

ช

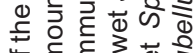

० 틍

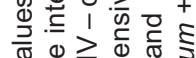

ब $0 \geq \frac{\bar{d}}{\sigma}$

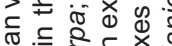

ब.

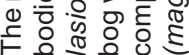


Juxtapositions of the Holocene subdivision schemes

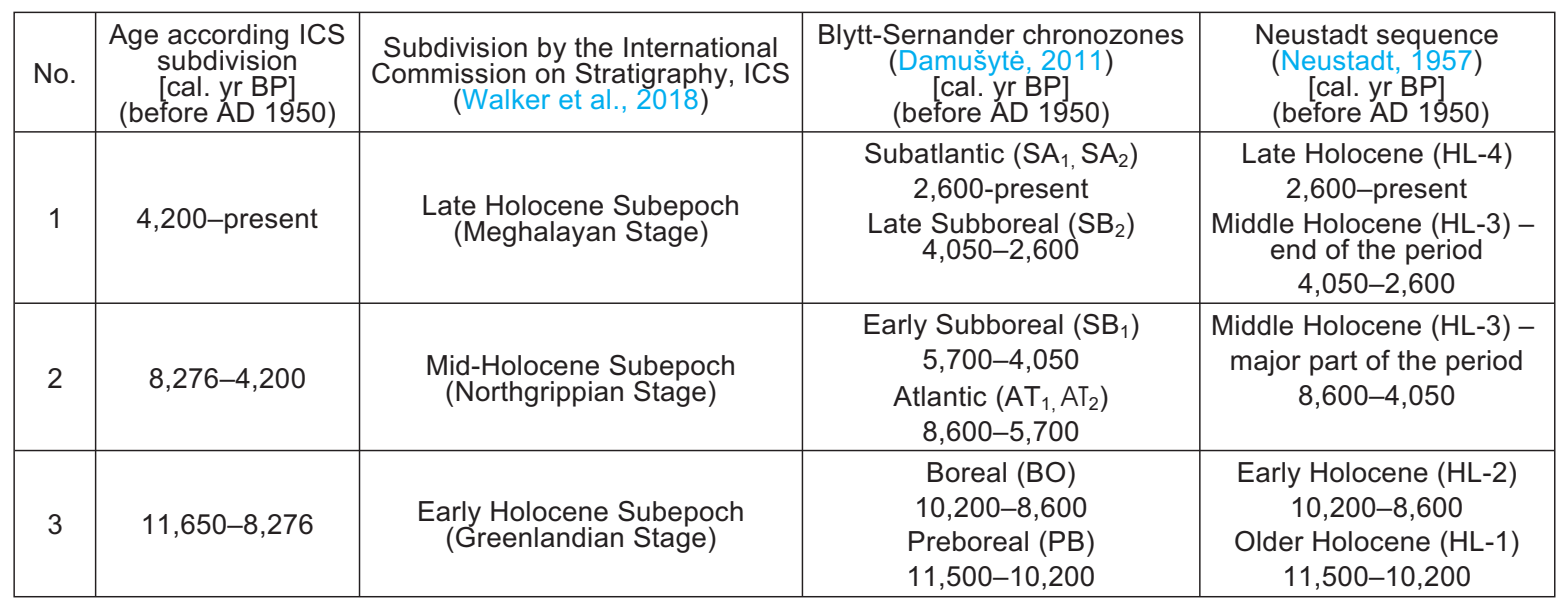

ing less numerous (20-30\%). Scheuchzeria palustris reaches $10 \%$. The hummock species, Sphagnum fuscum, disappears whereas Sphagnum magellanicum shows an increase at the top of the zone.

Macrofossil zone VII (81-13 cm, 400-60 cal. yr BP) shows a mixture of hummock and hollow bog Sphagna (S. magellanicum, S. cuspidatum S. angustifolium/S. fallax) dominating in this zone; together they exceed $90 \%$ of the residues. Scheuchzeria palustris reaches $5-7 \%$.

Macrofossil zone VIII (13-0 cm, 60 cal. yr BP - present). The dominant species are Sphagnum magellanicum and $S$. rubellum (55-80\%). The presence of Baeothryon cespitosus is an important characteristic of this zone. The percentage of the S. angustifolium / S. fallax group and Scheuchzeria palustris reaches $5-7 \%$.

\section{POLLEN DIAGRAM}

The pollen diagram (Fig. 5) was plotted based on the data from the deepest $(7 \mathrm{~m}$ ) peat core Kz-C of Koz'ye Bog spanning a period from the Late Glacial to the latest Holocene. Figure 5 presents seven local pollen assemblage zones (LPAZ) identified as described in Material and Methods.

LPAZ 1: Pinus-NAP (non-arboreal pollen species), (703-660 cm, 12,200-9,700 cal. yr BP). This zone is quite clearly separated from the rest of the diagram. Pollen from arboreal species dominates the general composition (75-80\%).

Arboreal species are mainly represented by the pollen of Pinus (41-58\%) and Betula sp. (20-43\%), a small amount of Salix sp. (1-3\%) and a trace amount of Alnus, Corylus and Picea. The percentage of herb pollen is the highest among the LPAZ, ranging from 17 to $25 \%$. The dominant taxa are Artemisia, Chenopodiaceae, Polygonaceae, Cichorioideae, Silene. Some Selaginella spores were also detected. An important characteristic of this pollen zone is the high content of the green freshwater alga Pediastrum boryanum.

LPAZ 2: Betula (660-645 cm, 9,700-8,800 cal. yr BP). This pollen zone is characterised by a visible rise and peak value in the percentage of Betula pollen $(<42 \%)$. This declines at the end of the zone with the simultaneous rise of the Pinus curve. The second important feature is an evident decrease in the percentage of NAP pollen, which falls to as low as $2 \%$ at the top.
The amount of Alnus and Salix increases up to 5\%. Quercus and Tilia are present, but only in small amounts (1-2\%).

LPAZ 3: Pinus-Alnus $(645-601 \mathrm{~cm}, 8,800-6,400$ cal. yr $B P)$. The lower boundary of LPAZ 3 is defined by a decrease in the amount of Betula pollen (3-16\%) and all non-arboreal species which coincides with an increase in the percentages of pollen from Pinus (50-86\%) and Alnus (4-37\%) and the appearance of Polypodiales spores. Some changes are evident from the middle of the pollen zone, in particular, an increase in the percentages of Corylus pollen and Polypodiales spores, the appearance of Tilia pollen and the extinction of Salix; however, the proportion of Picea pollen is still negligible. Based on the pollen spectra, LPAZ 3 may match the end of the Boreal and the beginning of the Atlantic chronozones, though the radiocarbon dates give a younger age for the upper part of this LPAZ.

LPAZ 4: Quercus-Tilia-UImus-Corylus (601-483 cm, $6,400-3,500$ cal. yr BP). The lower boundary of LPAZ 3 is marked by a decline in the Pinus pollen curve (14-50\%), a simultaneous increase in the percentage of pollen from Tilia $(<4.5 \%)$, Ulmus $(<8 \%)$ and Corylus $(<7 \%)$, and the appearance of Quercus pollen $(<10 \%)$. There is a substantial rise in the percentage of Alnus pollen (20-40\%), and the value of Picea also increases, especially towards the end of the pollen zone. LPAZ 4 can be correlated with the Atlantic and the first half of the Subboreal chronozones.

LPAZ 5: Alnus-Picea $(483-433 \mathrm{~cm}, 3,500-2,700$ cal. yr $\mathrm{BP})$. The lower boundary of this pollen zone is defined by a considerable increase in the percentage of Alnus pollen (40-71\%) and a simultaneous decline in the amount of pollen from thermophilic tree species of the nemoral assemblage: Ulmus, Quercus, Corylus and Tilia. When compared with the other pollen zones, the percentage of spruce (Picea) pollen is higher, hornbeam (Carpinus) pollen appears, single pollen grains of buckthorn (Frangula alnus) are found, and Polypodiales spores occur throughout the whole pollen zone. Based on the pollen spectra, LPAZ 5 may be correlated with the second half of the Subboreal chronozone.

LPAZ 6: Carpinus - Picea (433-43 cm, 2,700-250 cal. yr $\mathrm{BP})$. The lower boundary is defined by a decrease in the percentage of Alnus pollen and a simultaneous increase in the pollen concentration of Betula, Corylus, Carpinus, Quercus, Ericaceae (including Calluna) and some terrestrial herbaceous 


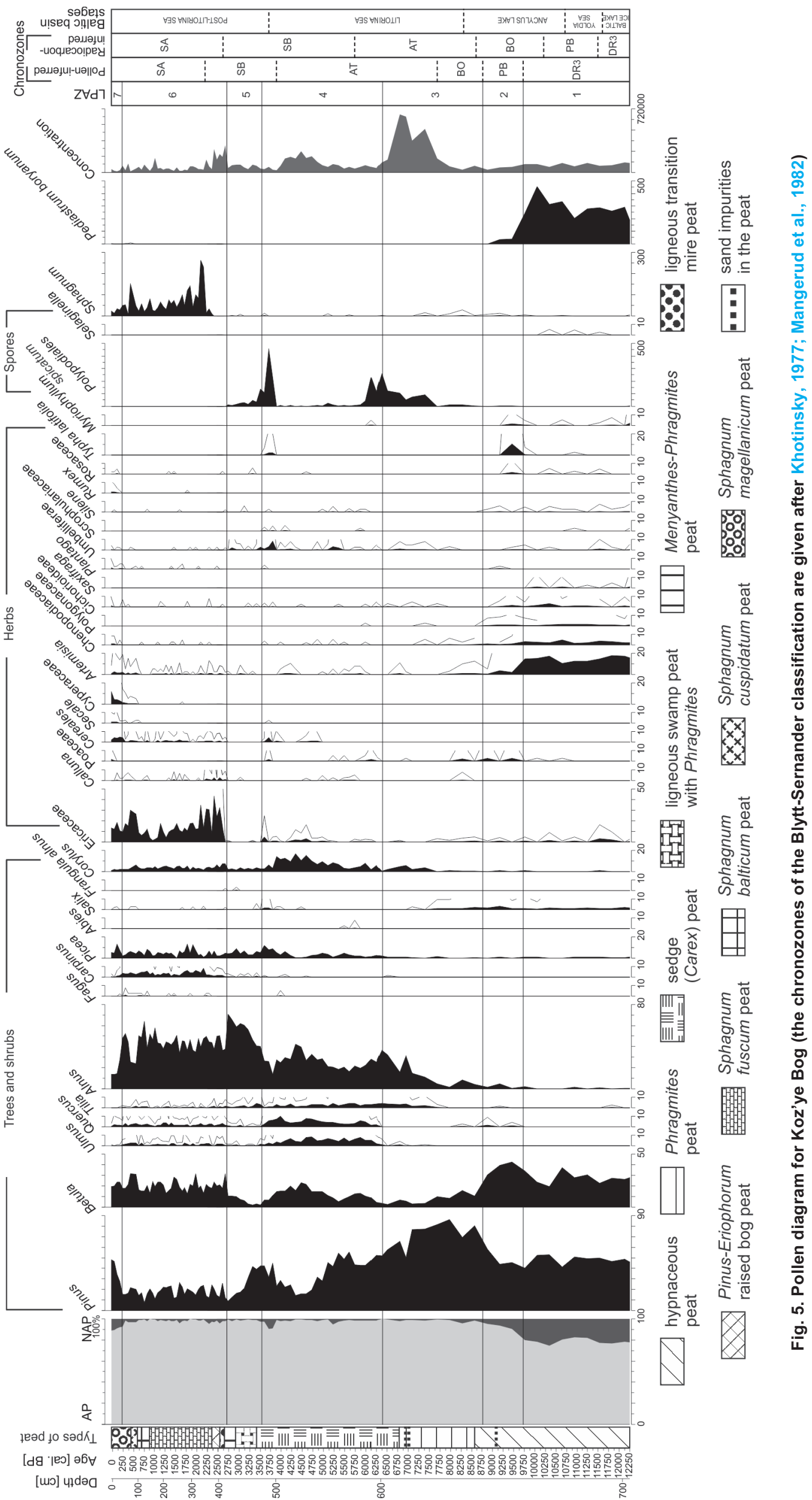


plants (Cereales, Artemisia). The percentage of Picea pollen is still high, pollen from Pinus, Tilia and Ulmus is common, and single buckthorn (Frangula alnus) pollen grains are also present. This pollen zone matches most of the Subatlantic chronozone.

LPAZ 7: Pinus-Picea-NAP (43-6 cm, 250 cal. yr BP present time). This pollen zone matches the latest Subatlantic chronozone and illustrates the obvious anthropogenic impact distinctly identified by the considerable percentage of herbs $(11 \%)$ that include cereals (Secale-type) and synanthropic species (Artemisia, Chenopodiaceae), and the essential increase in the value of Pinus and Picea. By contrast, the percentage of all nemoral arboreal species (Alnus, Ulmus, Tilia, Quercus, Corylus, Carpinus) declines by a great extent whilst the pollen of Fagus disappear. There is a decline in the amount of Sphagnum spores, which likely indicates a decrease in the growth rate of peatland, in the last 100-150 years, caused by drainage.

\section{DISCUSSION}

\section{MIRE FORMATION IN THE AREA OF THE KOZ'YE BOG}

The macrofossil diagram indicates that the peat formation process began during the Younger Dryas chronozone $\sim 12,100$ cal. yr BP in a low-productivity pool dominated by hydrophilic bryophytes with a minimal peat accumulation rate (macrofossil zone I). The large amount of Pediastrum boryanum coenobia in the pollen diagram (Fig. 5) indicates the existence of a water body during this period, while further up the core, the amount of Pediastrum boryanum gradually decreases and finally ceases with the simultaneous appearance of Typha latifolia pollen, indicating the occurrence of shoaling.

Residues from Carex lasiocarpa and Phramites appeared in the same period on the macrofossil diagram (Fig. 4), it is clear that aquatic communities were replaced 8,600 cal. yr BP by mesotrophic fen vegetation dominated by Phragmites and Carex. These indicators reflect a process of terrestrialisation which occurred in the existing water body resulting in the formation of a fen.

So, the pioneer wetland stage lasted $\sim 3,500$ years and spanned the end of the Late Glacial and the whole early Holocene (the Younger Dryas, Preboreal and Boreal).

Tussocky fen vegetation (macrofossil zones II and III) was dominant here during a long period of nearly 5,000 years which spanned the entire Atlantic and most of the Subboreal chronozones (8,600-3,500 cal. yr BP). This phase was also characterised by generally low organic accumulation.

Macrofossil zone IV shows that there was a rapid replacement of the fen vegetation by the transition mire that existed here during an 800-year period in the late Subboreal and the early Subatlantic chronozones (3,500-2,300 cal. yr BP).

Macrofossil zone $\mathrm{V}$ indicates that there was rapid colonisation of the territory by Sphagnum fuscum-dominated raised bog communities at 2,300 cal. yr BP. This led to a considerable increase in the peat accumulation rate, which may have also been affected by climatic fluctuations in the Subatlantic.

The brief zones VI, VII and VIII reflect stages of vegetation succession and environmental alteration which were induced, presumably, both by natural factors (the development of the bog micro- and meso-topography, hydrographic conditions and climatic changes) and anthropogenic influence in the late Subatlantic during the last 800 years.

At the same time, the macrofossil diagram does not reveal any obvious marks of an inundation or submersion of the area during the Baltic transgressions within the entire study period.

\section{DEVELOPMENT OF THE LATE GLACIAL \\ AND HOLOCENE ENVIRONMENTS}

Based on the macrofossil analysis results, the lithological correlation of the peat cores, the pollen analysis and radiocarbon dating of the Koz'ye Bog deposits, several stages can be identified within the development of the Late Glacial and Holocene environments in the Russian part of the Neman Delta area. Since the study area is located in a coastal region, the main sea-level oscillations of the Baltic could, to a certain extent, have influenced the process of vegetation development and mire formation which, in its turn, should be reflected in the pollen spectra, lithostratigraphic profile and mire palaeo-succession diagram (Figs. 2-4). These data are summarised in a final chart (Fig. 6) indicating main environmental variations revealed in the studied area during the Late Glacial and Holocene.

The Younger Dryas, Preboreal and Boreal chronozones, 12,200-9,700 cal. yr BP (within LPAZ 1): an open cryophilic landscape, a delayed response to the global early Holocene warming. The pollen spectra indicate that a significant role was played by key cryophilic elements, which were common in tundra-like communities in the Younger Dryas chronozone. In particular, (1) a wide range of non-arboreal steppe-tundra species and an abundance of their pollen (Artemisia, Chenopodiaceae, Polygonaceae), (2) the presence of light-demanding cryophilic elements (Saxifraga, Selaginella), (3) a slight but distinct increase in the percentage of Salix pollen, and (4) the absence of thermophilic broad-leaved species. The pollen arrangement in LPAZ 1 may reflect a cryophilic open landscape with scattered patches of forest communities.

These features may have been a response to the climatic shift within the glacial stadial GS-1 in the North Atlantic (Alley, 2000; Litt et al., 2001; Boussman and Vierra, 2012) causing severe - cooler and drier - environmental conditions with a more distinct climatic continentality when compared with the subsequent Holocene environments. Similar vegetation traits were present in the adjacent Baltic regions in the Younger Dryas (Ralska-Jasiewiczowa et al., 2004; Kabailienè, 2006; Apolinarska et al., 2012; Gałka et al., 2014; Stančikaité et al., 2015; Zernitskaya et al., 2019) as well as in most of Europe (Neustadt, 1957; Gudelis, 1975; Lang, 1994; Litt et al., 2001) and North America (Boussman and Vierra, 2012).

At the same time, most of these climate indicators usually show a distinct decrease or disappearance during the transition from the Late Glacial to the Holocene $(11,650 \mathrm{cal}$. yr BP). Nevertheless, our dating and further interpolation give a broader temporal interval for this stage (Fig. 5, LPAZ 1) and therefore suggests that this type of vegetation was also common here at a later time, at least up to the middle of the Boreal $(\sim 9,700-9,500$ cal. yr BP).

The existence of the cold conditions that affected LPAZ 1 are also supported by the corresponding plant macrofossil data (Figs. 2 and 4, macrofossil zone I) which are mainly represented by the remnants of Drepanocladus, a hydrophilic moss predominant in tundra lake communities. According to earlier data (Steffen, 1931; Benrath, 1934; Pobedimova, 1955; Bitinas et al., 2002), hydrophilic bryophyte communities containing Drepanocladus were widespread in the southeastern Baltic Region during the Preboreal. Benrath (1934) suggested a similar age for the bottom horizons of the peat bed in the eastern part of the Koz'ye Bog (Bredschuller Moor). He inferred that these limnic gyttja deposits with considerable humidification developed via a paludification process on the older morainic terrace during the Ancylus transgression.

Our dating gives a time frame of 12,200-8,600 cal. yr BP for these peat deposits (Fig. 4, macrofossil zone I), showing that 
they formed in the, presumably, similar environments of a cold and dry climate during a long period that spanned a major part of the Younger Dryas, the entire Preboreal and the initial half of the Boreal chronozones.

Thus, we may assume the existence of cryophilic tundra-like or steppe-tundra vegetation, or at least fragments of such vegetation, in this territory up to the mid-Boreal ( 9,700-9,500 cal. yr BP). However, other areas of the region clearly show the spread of birch and pine forests during this time (Napreenko-Dorokhova, 2015; Druzhinina et al., 2015; Napreenko and Napreenko-Dorokhova, 2020). This also took place in neighbouring regions of northern Poland (Kołaczek et al., 2013; Fiłoc et al., 2014; Gałka et al., 2014), Lithuania (Kabailienè, 2006; Stančikaitè et al., 2015) and Belarus (Zernitskaya et al., 2019). The reasons for the supposed palaeogeographic delay are still unclear at present.

Emphasising the contrasting pollen sequences for the areas mentioned above, especially for those sites located in the southeastern part of the Kaliningrad Region (Druzhinina et al., 2015,2020 ), we should, however, note that this area had already become ice-free, during the retreat of the ice sheet to the line of the South-Lithuanian end moraines (Uścinowicz, 1999; Gaigalas et al., 2001; Kazakauskas and Gaigalas, 2004). As is shown in these papers and based on the estimated ice sheet recession rate in this region of $50 \mathrm{~m} / \mathrm{yr}$ (Lasberg and Kalm, 2013), this should have occurred $\sim 15,000$ cal. yr BP, i.e. $\sim 2,000$ years earlier than in the Neman Delta area where final deglaciation was recorded not later than $13,600-13,300$ cal. yr BP (Rinterknecht et al., 2008; Lasberg and Kalm, 2013). Hence, the vegetation cover began to develop much earlier in the southern parts of the Kaliningrad Region while the northwestern territories were still occupied by the glacier. This may have been also among the possible causes that have influenced the course of vegetation development in the study area.

Meanwhile, some sites located in the area of the Last Glaciation ice retreat limits of the North-Lithuanian and Middle-Lithuanian phases (Gaigalas et al., 2001; Kazakauskas and Gaigalas, 2004) show pollen data similar to ours. These are pollen diagrams from the Lopaičiai Kettle in the Samogitian Upland, NW Lithuania (Kabailienè et al., 2015) and a small peatland in the erosional valley between the Sheshupe and Instruch rivers, in the northern part of the Kaliningrad Region (Bitinas et al., 2017). In particular, they show a high percentage of non-arboreal xerophilic (steppe-tundra) elements, such as Artemisia, Chenopodiaceae, Ephedra, Poaceae, up to the end of the early Boreal $(9,300-9,000$ cal. yr BP). The Lopaičiai diagram demonstrates also the dominance of Pinus up to 7,500 cal. yr BP (mid-Atlantic) and expansion of broad-leaved trees not earlier than 7,000 cal. yr BP (late Atlantic). These facts may also have been related to the late ice sheet retreat, and therefore to some probable climatic peculiarities of the sites located in the coastal regions.

In spite of a great number of papers showing a rapid shift in the mean annual and summer temperatures during the Late Glacial-Holocene transition and their further gradual rise in the early Holocene, there are some studies that consider the delayed warming during this period as a result of the regional patterns of climate evolution in the south and eastern Baltic (von Grafenstein et al, 1999; Subetto et al., 2000; Wolfahrt et al., 2007; Lauterbach et al., 2011). The authors of these associated the later climate amelioration and related response in the vegetation changes with such factors as the cold temperature of the surface waters of the Baltic Ice Lake, the proximity of high-pressure cells above Northern Europe as well as the related easterlies of increased strength, extensive permafrost, and stagnant ice.
Taking into account the coastal location of the study area, all these factors might have had an impact on the local environment, which, when combined with the poor soils of the morainic terrace, may have led to a persistence of cryophilic vegetation in the dune and morainic landscape in this area up to the second half of the Boreal. Nevertheless, this question requires more proxy data to be answered.

The late Boreal and Atlantic chronozones, 9,700-6,400 cal. yr BP (within LPAZ 2 and 3): gradual warming, an inundation of the area, and the dominance of birch and pine forests. LPAZ 2 shows a clear decline of NAP and an increase of AP, which demonstrates that Betula was widespread. This may indicate a transition from open cryophilic vegetation to the dominance of birch, presumably within a forest-tundra landscape. According to the aforementioned references on the palaeogeography of the adjacent regions, this change in the pollen spectra is typical of the end of the Younger Dryas and Preboreal in the 12,100-10,800 cal. yr BP interval. In our case, cryophilic elements underwent a conspicuous decline in their percentage totals within an interval $9,700-8,700$ cal. yr BP (Fig. 5) with a simultaneous rise in the amount of the arboreal pollen. This transition in Koz'ye Bog occurred in the last half of the Boreal chronozone (Fig. 5), which reveals that there was a time lag in the study area's environmental chronology of $\sim 1,000-2,000$ years when compared to other Baltic regions (Fig. 5, see comparison of the pollen-inferred and radiocarbon-inferred chronozone subdivision).

The pollen curves within LPAZ 3 indicate that this was when pine forests reached their maximum extent, and that broad-leaved forests started to spread in the study area shortly after this. This illustrates that the climate was warming.

Simultaneously, a substantial decrease in the number of birch stands occurred whilst the spread of the alder carr woodlands began. The latter, however, according to the percentage of Alnus pollen (on average $20 \%$ ), were not as wide spread as in the Late Holocene and occupied only separate flooded depressions. Nevertheless, during the latter half of this stage, alder carrs developed and expanded to new areas in the study region. All these alterations are demonstrated by the considerable amount of Alnus pollen and Polypodiales spores in the pollen diagram (Fig. 5) as well as by the sedimentary characteristics of the Phragmites fen peat (Figs. 3-5).

The boundaries of this stage comprise the period of three transgressions in the Baltic basin (Damušyte, 2011), which were related to the global rise in the level of the World Ocean. This is the final stage of the Ancylus transgression ( $A$, $9,200-8,300$ cal. yr BP) and two Littorina transgressions $\left(L_{1}\right.$, $8,300-8,000$ cal. yr BP and $L_{2}, 7,500-7,000$ cal. yr BP); the latter had an important impact on coastal regions.

According to a number of geological data sets (Bitinas et al., 2002; Gelumbauskaitè, 2009; Damušytè, 2011), the shoreline did not exceed the present-day Baltic sea level during the Ancylus and the first Littorina transgressions, but was 6-10 m below it (Damušytè, 2011).

On the other hand, according to the same sources (Bitinas et al., 2002; Gelumbauskaite, 2009; Damušyté, 2011), the rise in the water level exceeded the present-day shoreline position by several metres during the second, the most pronounced, Littorina transgression $\left(\mathrm{L}_{2}, 7,500-7,000\right.$ cal. $y r$ BP) which led to the submergence of a large area in the study region of the Lower Neman lowland. Based on the available cartographic data (Damušytè, 2011), the coastline extended several kilometres east of the present-day location of Koz'ye Bog, having exceeded the current shoreline level by $3 \mathrm{~m}$.

Our data may indicate the possibility of such transgression events during that period. 
1. The peat bed contains an admixture of sand at two horizons $(615 \mathrm{~cm}$ and $613 \mathrm{~cm})$ with an interpolated age of 7,000 and $6,900 \mathrm{cal}$. yr BP respectively, and then the structure of the peat deposits changed abruptly in (Fig. 5).

2. The peat deposits contain a considerable amount of mud in this part of the core.

3. The pollen concentration increases sharply in this part of LPAZ 3 (from 12,000 up to 30,000-40,000 pollen grains per $\mathrm{cm}^{3}$ ), furthermore, poorly preserved pollen grains are frequently found in the area, which are likely to have been redeposited here.

4. The pollen diagram (Fig. 5) shows that the curve peak of the fen ferns (Polypodiales) matches this period, i.e. the dominance of hygrophilic plants that were deposited in situ.

This may mean that the study region was partially submerged by sea-water during the second Littorina transgression, which may have led to the interruption of peat deposition in Koz'ye Bog and additionally influenced a delay in the appearance of nemoral-assemblage thermophilic species (Quercus, Ulmus, Tilia) in the pollen diagram (Fig. 5). Their expansion was recorded in the diagram only at 7,500 cal. yr BP (Tilia) or 6,500 cal. yr BP (Quercus, Ulmus).

Thus, these transgression-induced factors, such as the submergence of the area and the high ground water level, may have contributed to the fact that thermophilic broad-leaved species are recorded in this area 1,000-2,000 (and in some cases 3,000 ) years later than in other regions of the southeastern Baltic, where their expansion had already started during the early Atlantic or even the late Boreal, 9,500-8,600 cal. yr BP, (Kabailienè, 2006; Koůaczek et al., 2013; Gałka et al., 2014; Stančikaitë et al., 2015; Napreenko and Napreenko-Dorokhova, 2020). However, the regional peculiarities which affected the development of the climate may also be considered as among the possible causes.

The Late Atlantic and the initial half of the Subboreal chronozones, 6,400-3,500 cal. yr BP (within LPAZ 4): the maximum extent of nemoral-assemblage species. The pollen data demonstrates an expansion of deciduous forests in the Lower Neman lowland that occurred during this period. The character of the pollen spectra arrangement shows a distribution maximum of deciduous forests in the surrounding vegetation, indicating the formation of a warmer environment favourable for dispersal of species-rich temperate (nemoral) broad-leaved communities also known as Quercetum mixtum.

The widespread distribution of Alnus was favoured by the near-sea level location of the territory and the area having an undulating relief with numerous depressions. According to the published data (Steffen, 1931; Pobedimova, 1955), black alder (Alnus glutinosa) spread in the region of the southeastern Baltic coast in the late Boreal chronozone, during the Ancylus transgression. However, this process occurred in the northern part of the Lower Neman lowland at a much slower rate. So, even in the Atlantic chronozone, the distribution of Alnus did not reach its maximum there. This was also the case for the neighbouring territory of Lithuania (Gudelis, 1975).

Unlike the previous pollen zone, LPAZ 4 does not reveal any clear indications of the impact of the transgression on the vegetational development process. Although there is a local peak of Alnus pollen that matches the peak value of the mire fern spores (Polypodiales) at the very beginning of LPAZ 4; with the sporadic appearance of Myriophyllum pollen, this may indicate a short-term inundation of the area along the edge of the peatland.

During the third Littorina transgression $\left(L_{3}, 4,700-4,100\right.$ cal. yr BP), according to available data (Bitinas et al., 2002;
Damušytė, 2011; Kublitsky, 2016), the shoreline only shifted several kilometres eastwards from the present-day position and most likely reached the western margin of Koz'ye Bog. Bitinas et al. (2002) proposed that the large mires in the northern part of the Neman Delta (Augstumal, Rupkalviai) were located along the coastline during this period, surrounding a shallow water bay. Koz'ye Bog appears to be a continuation of this chain of mires.

The final part of LPAZ 4 correlates with the middle of the Subboreal chronozone and the initial stage of the Post-Littorina transgression (PL, 3,700-2,400 cal. yr BP). The sea level of the study area was 3-4 metres lower than its present level, which should not have led to submergence of the territory; however, in the northernmost parts of the delta, the sea level rose 2-4 m (Damušytè, 2011). The pollen diagram (Fig. 5) shows a distinct peak in the Polypodiales spore curve at these horizons, together with an occurrence of Typha pollen, a plant of aquatic habitats. There was also a certain amount of poorly preserved Alnus pollen in the peat horizons that matches the upper part of LPAZ 4, while the total amount of Alnus pollen decreased abruptly for a short time. These observations may suggest that there was a short-term inundation of the territory.

As noted earlier (Bitinas et al., 2002), the process of peatland development distinctly intensified in this region during the regression of the Littorina Sea between the second and third transgressions $(7,000-4,700$ cal. yr BP). Nevertheless, the peat accumulation rate remained rather low $0.4-0.5 \mathrm{~mm} / \mathrm{yr}$ (Fig. 3), probably due to the simultaneous rapid decomposition of the peat in response to the milder climate and higher groundwater table, which impeded the transition of the mire into a raised bog. In this context, it is more appropriate to use the term "mire formation" rather than "bog development" as used in Bitinas et al. (2002), since the mires in this region remained at the fen stage, with the flora including Carex lasiocarpa, up to the beginning of the Subatlantic chronozone (2,300 cal. yr BP for Koz'ye Bog). It was only after this that the rapid development of raised bogs began (NapreenkoDorokhova et al., 2017; Napreenko-Dorokhova and Napreenko, 2018). Deciduous forests of the nemoral assemblage were dominant in the surrounding areas during the Atlantic and the first half of the Subboreal chronozone. As we reported earlier (Napreenko-Dorokhova, 2015; Napreenko-Dorokhova et al., 2017), the climatic conditions during the initial half of the Subboreal chronozone (5,700-4,000 cal. yr BP), especially in the coastal areas, were similar to those in the Atlantic chronozone. This became an important factor which promoted the existence of deciduous forests in the area. Nevertheless, the pollen diagram (Fig. 5) shows an evident increase in the percentage of spruce (Picea) pollen in the upper part of LPAZ4. The first half of the Subboreal chronozone is considered to be a period when the forests were undergoing gradual restructuring, in short, there was a transition from deciduous broadleaf forests into spruce-broadleaf communities in the study region, resulting in the formation of a specific zonal vegetation type which was a characteristic feature of the Southeastern Baltic Region during the Late Holocene and remains so until this day (Napreenko and Napreenko-Dorokhova, 2020).

The late Subboreal, 3,500-2,700 cal. yr BP (within LPAZ 5): a short-term inundation, the expansion of alder carrs. According to the published data (Steffen, 1931; Neustadt, 1957; Usinger, 1975; Göttlich, 1990; Lang, 1994; Latałowa and Knapp, 2006; Giesecke et al., 2017; Novenko et al., 2018), the Subboreal chronozone was a time when the range of spruce was expanding, spreading from Eastern Europe; at the same time, beech forests became widely distrib- 


\section{Chronozones}

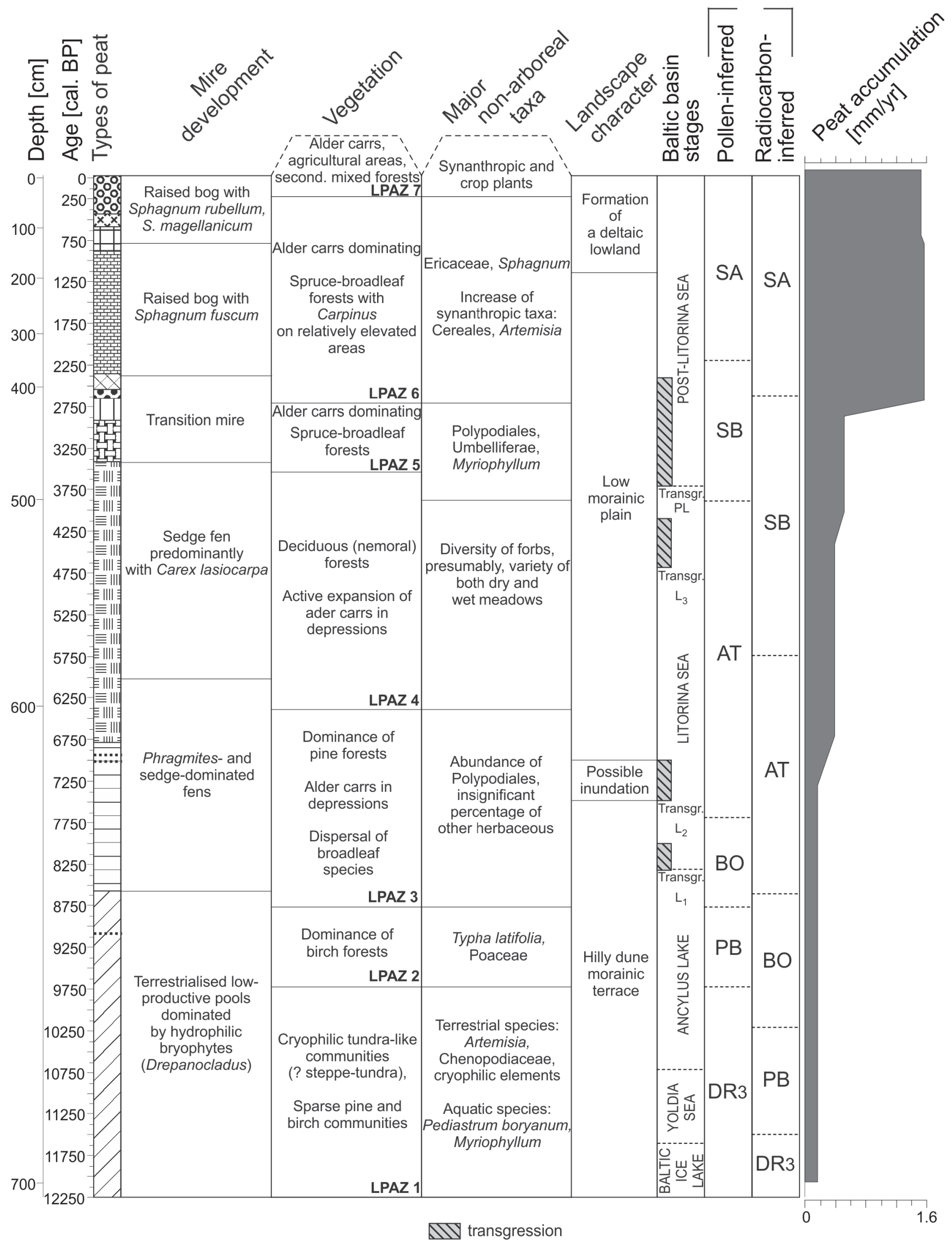

Fig. 6. Summary chart indicating the main Late Glacial and Holocene environmental variations in the Koz'ye Bog area 
uted in coastal regions. The pollen diagram (Fig. 5) shows that beech (Fagus) did not spread in the study area, while spruce (Picea) was increasing throughout the territory of the northern part of the Lower Neman lowland. Therefore, it may be assumed that spruce-broadleaf forests were common here during the final half of the Subboreal chronozone. Their structure was similar to the present-day broadleaf-conifer forests typical of the central part of the Kaliningrad Region which contain spruce and oak in the main canopy and an understorey of hornbeam and hazel (Napreenko and Napreenko-Dorokhova, 2020).

At the same time, black alder (Alnus glutinosa) reached its maximal distribution in the area; this was presumably caused by the high groundwater table and storm surges which may have led to inundation of the territory. This factor, in turn, accelerated the mire formation process in this landscape area, having facilitated a wide distribution of the alder carr ecosystems. These habitats are a distinctive landscape feature of the Neman Delta area.

According to the cartographic reconstructions (Damušytè, 2011; Kublitsky, 2016), part of the study area remained submerged by the waters of a shallow, 1-2 $\mathrm{m}$ deep, lagoon of the Post-Littorina Sea that was in a stage of transgression $(3,700-2,400$ cal. yr BP). Damušyte (2011) reported that the shoreline was several kilometres east of Koz'ye Bog, though the data from our investigations does not reveal any traces of peat bed submergence. As can be seen from the composition of plant macrofossils in the peat samples (Fig. 4, stage IV), by that time, the primary mire kettle contained an already thick bed of peat deposits $(\sim 3 \mathrm{~m})$, on which a transition mire started to form (Menyanthes, bark of Pinus). There was a change from Carex peat to ligneous peat with Phragmites, while the rate of peat accumulation increased slightly to $0.5 \mathrm{~mm} /$ year (Figs. 2 and 4 ) in the upper half of the pollen zone.

The Subatlantic chronozone, 2,700-250 cal. yr BP (within LPAZ 6): spruce-broadleaf forest development, deltaic landscape formation. The pattern of the pollen spectra within LPAZ 6 indicates that wet alder communities and broadleaf-coniferous forests were widely distributed and were, in spite of their structural changes, characterised by varied species compositions. On the whole, the vegetation is similar to that of the previous pollen zone. The sites at higher locations were dominated by mixed spruce-broadleaf communities, which are still common throughout the entire southeastern Baltic region (Leontiev, 1955). However, when compared with the previous pollen zone, the composition of these forests were changed to some extent since hornbeam (Carpinus) became more significant in this pollen zone, apparently, due to a decline of the role of other broadleaf species.

There was an extensive formation of bogs and an increase in the percentage of ericaceous pollen (Ericaceae incl. Calluna) and the formation of the Sphagnum fuscum peat type (Fig. 5) which indicates that the mire was entering the raised bog stage. The peat accumulation rate remained rather high (up to $1.6 \mathrm{~mm} / \mathrm{yr}$ ), and the Sphagnum peat layers exceeded the edges in some mire kettles and merged to form a wider bog development, having formed a new natural elevation within the surrounding lowland landscape (Fig. 2).

At the same time, the shoreline of the Post-Littorina Sea retreated gradually, having reached its current position (Damušytè, 2011). In the middle of the Subatlantic chronozone $(1,100-1,000$ cal. yr BP), different alluvial processes started to sculpt the present-day topography of the delta (Bitinas et al., 2002), leading to the development of a landscape of coastal deltaic lowlands formed by alluvial and mire deposits. Wet alder carrs and large mires were the dominant ecosystems in this landscape across large areas. The scattered crests of ancient moraines and old dunes were occupied by spruce-broadleaf and pine forests.

The latest Subatlantic chronozone, $\sim 250$ cal. yr BP to the present (within LPAZ 7): human-induced landscape shifts. Since the second half of the XVIII century, substantial vegetational shifts, induced by anthropogenic impact, occurred both in the northern and southern parts of the Neman Delta (Napreenko-Dorokhova and Napreenko, 2018). Extensive land use and clear-cutting resulted in a substantial loss of broadleaf and spruce-broadleaf forests and, at the same time, caused an increase in agricultural areas and synanthropic habitats, as well as secondary pine and birch stands, in both territories.

In summary, as shown in the pollen diagram for Koz'ye Bog, there is a clear trend of decline in the percentage of Pinus pollen from the Late Glacial to the Late Holocene, and a simultaneous increase in the percentage of Alnus pollen. The course of the pollen curves illustrates that a structural change in the vegetation cover of this landscape area occurred, whereby the dominant pine forests were replaced by black alder carrs. We believe that this transformation was a response not only to changes in the climate but also to geomorphological transformations in the landscape structure of the territory, in particular, due to the erosion of the hilly coastal terrace caused by transgression during the formation of the Baltic. This led to a formation of a low coastal plain, the Lower Neman lowland. These findings are sufficiently corroborated by data on the Baltic transgressions (Bitinas et al., 2002; Damušytė, 2011).

Most of the Sphagnum peat was formed no later than during the last 2,300 years (see also the age-depth model and macrofossil diagram, Figs. 3 and 4). This shows that Koz'ye Bog is, in general, a relatively young geological object. The development of the mire took place during a long period of isolated kettles where the formation of the mires may have had different origins and, as can be deduced from the cross-section (Fig. 2), different courses of vegetation change. The formation of the entire mire system began only during the period when Sphagnum-dominated communities were rapidly distributed in the Late Holocene, when peat deposits in the separate kettles merged and formed an entire peat bed that became the basis of the large raised bog.

\section{CONCLUSIONS}

Our assessment of the data has enabled us to identify the general course of environmental development in the region of the present-day Lower Neman lowland during the Late Glacial and the Holocene.

1. During the Younger Dryas, Preboreal and Boreal chronozones $(12,200-8,800$ cal. yr BP), the general landscape topography was represented by a flat sandy terrace of the Baltic Ice Lake, and then the Yoldia Sea and Ancylus Lake, with numerous dunes and small terrestrialised pools in inter-mound depressions. A vegetational transition from cryophilic tundra-like sparse communities to pine and birch forests occurred in the late Boreal time $(9,700-8,700$ cal. yr BP), with a temporal delay of $\approx 1000-2000$ years. The persistence of severe environments and cryophilic vegetation may perhaps be explained by some regional patterns of climate development, the coastal location of the territory and its topographic peculiarities. Nevertheless, this question needs further study.

2. Three transgression events occurred during a period from the late Boreal to the late Atlantic chronozones $(8,800-6,400$ cal. yr BP). The final stage of the Ancylus trans- 
gression $(9,000-8,300 \mathrm{cal}$. yr BP) and the entirety of the first Littorina transgression $(8,300-8,000$ cal. yr BP), did not lead to a rise in the sea level above the present-day shoreline position, whereas the second Littorina transgression $(7,500-7,000$ cal. yr BP) led to the inundation of a vast area.

The climatic environments were presumably characterised by cooler conditions with gradually increasing mean annual temperatures. Pine forests were predominant. The first broadleaf communities, indicative of milder climatic conditions, occurred here later than in other parts of the southeastern Baltic Region by $1,000-2,000$ years. The possible submergence of the territory and the regional climate development pattern are to be considered among the causes of this delay. Alder carrs started to develop whilst mires in the inter-mound kettles were represented by Phragmites-dominant communities.

3. The expansion of nemoral deciduous forests was recorded during the Atlantic and the early Subboreal chronozones $(6,400-3,500$ cal. yr BP). They were dominant on interfluve sites, while alder carrs occupied topographic depressions. During the third Littorina transgression $(4,700-4,100 \mathrm{cal}$. yr BP), it is very likely that the the coastline came close to the western boundary of Koz'ye Bog.

4. The late Subboreal chronozone (3,500-2,700 cal. yr BP) saw the Post-Littorina transgression (3,700-2,400 cal. yr BP) which might have led to a brief inundation of the territory. The high groundwater table and storm surge events encouraged the widespread distribution of alder carr habitats which became characteristic of this landscape area. The formation of spruce-broadleaf forests began and large mire ecosystems accumulated substantial peat deposits which prevented their flooding with lagoon waters and enabled them to enter the stage of transition mires.

5. During the Subatlantic chronozone $(2,700-250$ cal. yr $\mathrm{BP}$ ), alder carrs were still widespread, though a further expansion of mixed spruce-broadleaf forests occurred. However, hornbeam played a more significant role in the structure of these forests than it did previously. Large mires entered the raised bog stage and merged into entire bog massifs; this indicates a high rate of Sphagnum peat accumulation (up to $1.6 \mathrm{~mm} / \mathrm{yr}$ ).

6 . There were vegetational shifts and landscape transformations induced by considerable human impact in the latest Subatlantic chronozone (since the XVIII century).

7. The development of vegetation in the study area can be divided into four main stages: (1) cryophilic tundra-like vegetation in the Late Glacial and Early Holocene; (2) the dominance of pine forests at the beginning of the mid-Holocene; (3) the expansion of nemoral deciduous forests (Quercetum mixtum) and alder carrs in the mid-Holocene; (4) the dominance of alder carrs and spruce-broadleaf forests during the Late Holocene.

The first two stages were related to the hilly landscape of the coastal terrace, but the topography changed significantly after the transgressions of the Littorina Sea. This led to inundation of the area and erosion of the previous morainic relief. The territory became a flat coastal lowland with separate small elevations which encouraged the widespread expansion of wetland ecosystems in this area.

Acknowledgements. The fieldwork and analyses were performed under the state assignment of the Shirshov Institute of Oceanology (research theme no. 0128-2021-0012), laboratory treatment of peat samples was funded by the Russian Academic Excellence Project at the Immanuel Kant Baltic Federal University, the AMS-dating, data interpretation and review were supported by the Russian Science Foundation (project no. 18-77-10016). We thank Laimdota Kalnina and other reviewers for their constructive criticism and insightful advice. We are also grateful to Sebastian Archer, former Membership Development Officer at the London Wetland Centre (Wildfowl and Wetlands Trust) for editing the manuscript and improving the English text.

\section{REFERENCES}

Alley, R.B., 2000. The Younger Dryas cold interval as viewed from central Greenland. Quaternary Science Reviews, 19: 213-226.

Apolinarska, K., Woszczyk, M., Obremska, M., 2012. Late Weichselian and Holocene palaeoenvironmental changes in northern Poland based on the Lake Skrzynka record. Boreas, 41: 292-307.

Benrath, W., 1934. Untersuchungen zur Pollenstatistik und Mikrostratigraphie von Tonen und Torfen in Randgebieten des Kurischen Haffs unter Berücksichtigung metodischer Fragen. Albertus-Universität, Königsberg.

Beug H.-J., 2004. Leitfaden der Pollenbestimmung für Mitteleuropa und angrenzende Gebiete. Verlag Dr. Friedrich Pfeil, München.

Bitinas, A., Damušytè, A., Stančikaitè, M., Aleksa, P., 2002. Geological development of the Nemunas River Delta and adjacent areas, West Lithuania. Geological Quarterly, 46 (4): 375-389.

Bitinas, A., Druzhinina, O., Damušytè, A., NapreenkoDorokhova, T., Guobytè, R., Mažeika, J., 2017. The lower reaches of the Nemunas River at the end of the Last (Weichselian) Glacial and beginning oft he Holocene. Geological Quarterly, 61 (1): 156-165.

Boitsova, E.P., 1977. Nekotoriye predlozheniya po oformleniyu palinologicheskogo materiala (in Russian). In: Methods of Treatment of Palynological Data: 76-77. VSEGEI Press, Leningrad.
Boussman, B., Vierra, B.J., (eds.), 2012. From the Pleistocene to the Holocene: human organization and cultural transformations in prehistoric North America. Texas A\&M University Press.

Bronk Ramsey, C., 2017. Methods for summarizing radiocarbon datasets. Radiocarbon, 59: 1809-1833.

Damušytè, A., 2011. Post-glacial geological history of the Lithuanian coastal area. Summary of doctoral dissertation. Vilnius.

De Vleeshouwer, F., Chambers F.M., Swindles G.T., 2010. Coring and sub-sampling of peatlands for palaeoenvironmental research. Mires and Peat, 7: 1-10.

Dombrovskaya, A.V., Koreneva, M.M., Tyuremnov, S.N., 1959. Atlas rastitel'nykh ostatkov v torfakh (in Russian). State Energy Publisher, Moscow-Leningrad.

Druzhinina, O., Subetto, D., Stančikaitè, M., Vaikutienè, G., Kublitsky, J., Arslanov, Kh., 2015. Sediment record from the Kamyshovoe Lake: history of vegetation during late Pleistocene and early Holocene (Kaliningrad District, Russia). Baltica, 28: 121-124.

Druzhinina, O., Kublitskiy, Y., Stančikaitè, M., Nazarova, L., Syrykh, L., Gedminienè, L., Uogintas, D., Skipitytè, R., Arslanov, K., Vaikutienè, G., Kulkova, M., Subetto, D., 2020. The Late Pleistocene-Early Holocene palaeoenvironmental evolution in the SE Baltic region: a new approach based on chironomid, geochemical and isotopic data from Kamyshovoe Lake, Russia. Boreas, 49: 544-561. 
Faegri, K., Iversen, J., 1989. Textbook of Pollen Analysis. The Blackburn Press, Caldwell, NJ.

Faegri, K., Iversen, J., 1993. Bestimmungsschlüssel für die nordwesteuropäische Pollenflora. Gustav Fischer Verlag, Jena.

Fiłoc, M., Kupryjanowicz, M., Drzymulska D., 2014. Late Glacial and Holocene vegetation changes in the Wigry National Park, NE Poland - new pollen data from three small dystrophic lakes. Studia Quaternaria, 31: 5-16.

Gaigalas, A., Pazdur, A., Hałas, S., Pawlyta, J., Kazakauskas, V., 2001. Stable isotopes as record of climatic changes of Daniglacial in Lithuania. Geochronometria, 20: 81-86.

Gałka, M., Tobolski, K., Zawisza, E., Goslar, T., 2014. Postglacial history of vegetation, human activity and lake-level changes at Jezioro Linówek in northeast Poland, based on multi-proxy data. Vegetation History and Archaeobotany, 23: 123-152.

Gelumbauskaitè, L.Ž., 2009. Character of sea level changes in the subsiding south-eastern Baltic Sea during Late Quaternary. Baltica, 22: 23-36.

Giesecke, T., Brewer, S., Finsinger, W., Leydet, M., Bradshaw, R.H.W., 2017. Patterns and dynamics of European vegetation change over the last 15,000 years. Journal of Biogeography, 44: $1441-1456$.

Gudelis, V.K., 1975. Skhema paleogeograficheskogo razvitiya Pribaltiki v pozdne-poslelednikovoye vremya (in Russian). In: Geology of the Baltic Sea (eds. V.K. Gudelis and E.M. Emelianov). Mokslas, Vilnius.

Göttlich, K., 1990. Moor- und Torfkunde. Schweizerbart'sche Verlagsbuchhandlung, Stuttgart.

Juggins, S., 2014. C2 Version 1.7.6. Electronic resource. Mode of access: https://www.staff.ncl.ac.uk/stephen.juggins/software/C2Home.htm

Kabailiené, M., 2006. Late Glacial and Holocene stratigraphy of Lithuania based on pollen and diatom data. Geologija, 54: 42-48.

Kabailienė, M., Vaikutienè, G., Macijauskaitè, L., Rudnickaitè, E., Guobytè, R., Kisielienè, D., Gryguc, G., Mažeika, J., Motuza, G., Šinkūnas, P., 2015. Lateglacial and Holocene environmental history in the area of Samogitian Upland (NW Lithuania). Baltica, 28: 163-178.

Katz, N.Y., Katz, S.V., Skobeeva, E.I., 1977. Atlas Rastitel'nikh Ostatkov v Torfakh (in Russian). Nedra, Moscow.

Kazakauskas, V., Gaigalas, A., 2004. Varvometric estimation of the duration of Daniglacial glaciolacustrine sedimentation in Lithuania. Geologija, 48: 44-54.

Khotinsky, N.A., 1977. Golotsen Severnoi Evrazii (in Russian). Nauka, Moscow.

Kołaczek, P., Kupryjanowicz, M., Karpińska- Kołaczek, M., Szal, M., Winter, H., Danel, W., Pochocka-Szwarc, K., Stachowicz-Rybka, R., 2013. The Late Glacial and Holocene development of vegetation in the area of a fossil lake in the Skaliska Basin (north-eastern Poland) inferred from pollen analysis and radiocarbon dating. Acta Palaeobotanica, 53: 23-52.

Korotkina, M.Ya., 1939. Botanicheskiy analiz torfa (in Russian). In: Methods of Peat-bog Investigation (ed. M.I. Neustadt), Part 2: 5-59. The People's Commissariat for Agriculture of the RSFSR, Moscow.

Kublitsky, Yu.A., 2016. Dinamika prirodnikh usloviy yugo-vostochnoy chasti Baltiyskogo regiona $v$ pozdnem neopleystotsene i $\vee$ golotsene (in Russian). Ph.D. Thesis, Saint-Petersburg.

Kupriyanova, L.A., Alyoshina, L.A., 1972. Pil'tsa i Spori Rasteniy Flori SSSR (in Russian), 1. Nauka, Leningrad.

Lang, G., 1994. Quartäre Vegetationsgeschichte Europas. G. Fischer, Jena.

Latałowa, M., van der Knapp, W.O., 2006. Late Quaternary expansion of Norway spruce Picea abies (L.) Karst. Quaternary Science Review, 25: 2780-2805.

Lasberg, K., Kalm, V., 2013. Chronology of Late Weichselian glaciation in the western part of the East European Plain. Boreas, 42: 995-1007.
Lauterbach, S., Brauer, A., Andersen, N., Danielopol, D.L., Dulski, P., Hüls, M., Milecka, K., Namiotko, T., Plessen, B., von Grafenstein, U., DecLakes participants, 2011. Multi-proxy evidence for early to mid-Holocene environmental and climatic changes in northeastern Poland. Boreas, 40: $57-72$.

Leontiev, V.L., 1955. Nyekotoriye osobennosti lesov Kaliningradskoy oblasti (in Russian). Proceedings of the V.L. Komarov Botanical Institute of the Academy of Sciences of the USSR. Ser. III (Geobotany), 10: 329-372.

Litt, T., Brauer, A., Goslar, T., Merkt, J., Bałaga, K., Müller, H., Ralska-Jasiewiczowa, M., Stebich, M., Negendank, J.F.W., 2001. Correlation and synchronisation of Lateglacial continental sequences in northern central Europe based on annually laminated lacustrine sediments. Quaternary Science Reviews, 20: $1233-1249$

Mangerud, J., Birks, H.J.B., Jäger, K.D., 1982. Chronostratigraphical subdivisions of the Holocene: a review. Striae, 16: 1-6.

Matyushenko, V.P., 1939. Opredeleniye osok v torfe (in Russian). In: Methods of Peat-bog Investigation (ed. M.I. Neustadt), Part 1: 93-102. The People's Commissariat for Agriculture of the RSFSR, Moscow.

Minkina, Ts.l., 1939. Zondirovaniye torfyanoy zalezhi, raspredeleniye i vzyatiye prob na bolote (in Russian). In: Methods of Peat-bog Investigation (ed. M.I. Neustadt), Part 1: 31-63. The People's Commissariat for Agriculture of the RSFSR, Moscow.

Napreenko-Dorokhova, T.V., 2015. Paleoekologicheskaya rekonstruktsiya rastitel'nogo pokrova yugo-vostochnoy chasti Baltiyskogo regiona v golotsene (in Russian). Ph. D. Thesis, Kaliningrad.

Napreenko, M.G., Napreenko-Dorokhova, T.V., 2015. Botanicheskiy sostav torfov verkhovogo bolota Koz'ego $v$ del'te Nemana (in Russian). In: Soils in the Kaliningrad Region: Researches, Use, Current State Assessment, The Interuniversity Scientific Compendium Devoted to the International Year of Soils (eds. O.A. Antsiferova et al.): 140-152. Kaliningrad State Technical University, Kaliningrad.

Napreenko, M.G., Napreenko-Dorokhova, T.V., 2020. The main patterns of present-day zonal vegetation development in Kaliningrad Oblast, Russian Federation (southeastern Baltic), inferred by palynological data (in Russian with English summary). Vestnik of Saint Petersburg University, Earth Sciences, 65: 337-361.

Napreenko-Dorokhova, T.V., Napreenko, M.G., 2018. The history and pattern of forest and peatland formation in the Kaliningrad Region during the Holocene. The Handbook of Environmental Chemistry, 65: 121-146.

Napreenko-Dorokhova, T.V., Napreenko, M.G., Lisitzin, A.P., 2017. Pattern of large raised bog formation in the south-eastern Baltic Region during the Holocene: the case of Kaliningrad Oblast. Doklady Earth Sciences, 475: 900-906.

Nelle, O., 2006. Übung Pollenanalyse (Anweisungen zum Laborpraktikum in der Pollenanalyse). Ökologiezentrum, Universität Kiel, Kiel.

Neustadt, M.I., 1957. Istoriya lesov i paleogeografiya SSSR v golotsene (in Russian). Academy of Sciences of the USSR, Moscow.

Novenko, E.Yu., Tsyganov, A.N., Pisarchuk, N.M., Volkova, E.M., Babeshko, K.V., Kozlov, D.N., Shilov, P.M., Payne, R.J., Mazei, Yu.A., Olchev, A.V., 2018. Forest history, peatland development and mid- to late Holocene environmental change in the southern taiga forest of central European Russia. Quaternary Research, 89: 223-236.

Orlionok, V.V., (ed.), 2008. Geografiya Yantarnogo kraya Rossii (in Russian). Yantarnyi Skaz, Kaliningrad.

Piavtchenko, N.I., 1963. Stepen' razlozheniya torfa i metodi eyo opredeleniya (in Russian). Krasnoyarskiy rabochiy, Krasnoyarsk. 
Pobedimova, E.G., 1955. Sostav, rasprostraneniye po rayonam i khozyaystvennoye znacheniye flory Kaliningradskoy oblasti (in Russian). Proceedings of the V.L. Komarov Botanical Institute of the Academy of Sciences of the USSR. Ser. III (Geobotany), 10: $225-329$.

Ralska-Jasiewiczowa, M., Latałowa, M., Wasylikowa, K., Tobolski, K., Madeyska, E., Wright, H., Turner, Ch. (eds.), 2004. Late Glacial and Holocene History of Vegetation in Poland Based on Isopollen Maps. Polish Academy of Sciences, Kraków.

Rinterknecht, V.R., Bitinas, A., Clark, P.U., Raisbeck, G.M., Yiou, F., Brook, E.J., 2008. Timing of the last deglaciation in Lithuania. Boreas, 37: 426-433.

Stuiver, M., Reimer, P.J., Reimer, R.W., 2020. CALIB 8.2 [www program] at http://calib.org, accessed 2020-12-7.

Stančikaitè, M., Šeirienè, V., Kisielienè, D., Martma, T., Gryguc, G., Zinkutè, R., Mažeika, J., Šinkūnas, P., 2015. Lateglacial and the early Holocene environmental dynamics in northern Lithuania: a multy-proxy record from Ginkűnai. Quaternary International, 357: 44-57.

Steffen, H., 1931. Vegetationskunde von Ostpreußen. Verlag von Gustav Fischer, Jena.

Stockmarr, J., 1971. Tablets with spores used in absolute pollen analysis. Pollen et Spores, 13: 615-621.

Subetto, D.A., Wohlfarth, B., Davydova, N.N., Sapelko, T.V., Björkman, L., Solovieva, N., WastegÍrd, S., Possnert, G., Khomutova, V.I., 2000. Climate and environment on the Karelian Isthmus, northwestern Russia, 13,000-9,000 cal. yrs BP. Boreas, 31: 1-19.

Timofeev, P.P., Bogolyubova L.I., 1998. Sedimentogenesis and early lithogenes of the Holocene deposits seashore areas of peat accumulation (Kolkhida, southeastern Baltic, west Cuba, Florida) (in Russian with English summary). Nauka, Moscow.

Usinger, H., 1975. Pollenanalytische und stratigraphische Untersuchungen an zwei Spätglazial-Vorkommen in Schleswig-Holstein. Mitteilungen der Arbeitsgemeinschaft Geobotanik in Schleswig-Holstein und Hamburg, 25: 1-183.

Uścinowicz, S., 1999. Southern Baltic area during the last deglaciation. Geological Quarterly, 43 (2): 137-148.

Von Grafenstein, U., Erlenkeuser, H., Brauer, A., Jouzel, J., Johnsen S.J., 1999. A mid-European decadal isotope-climate records from 15,500 to 5,000 years B.P. Science, 284: 1654-1657.

Walker, M.J.C., Head, M.J., Berkelhammer, M., Björk, S., Cheng, H., Cwynar, L.C., Fisher, D.A., Gkinis, V., Long, A., Lowe, J., Newham, R., Rasmussen, S.O., Weiss, H., 2018. Formal ratification of the subdivision of the Holocene Series/Epoch (Quaternary System/Period): two new Global Boundary Stratotype Sections and Points (GSSPs) and three new stages/subseries. Episodes, 41: 213-223.

Wohlfarth, B., Lacourse, T., Bennike, O., Subetto, D., Tarasov, P., Demidov, I., Filimonova, L., Sapelko, T., 2007. Climatic and environmental changes in north-western Russia between 15000 and 8000 cal yr BP: a review. Quaternary Science Reviews, 26: 1871-1883.

Zernitskaya, V.P., Novenko, E.Yu., Stančikaitë, M., Vlasov, B.P., 2019. Environmental changes in the Late Glacial and Holocene in the southeast of Belarus (in Russian with English summary). Doklady of the National Academy of Sciences of Belarus, 63: 584-596. 